\title{
US adopts economy and civilian use as new goals for military research
}

Washington. The US Department of Defense (DoD) has announced that, for the first time, the affordability and possible commercial use of new military technologies will become key objectives of its $\$ 36$ billion-ayear research and development programme, not merely technological supremacy.

Describing this shift in emphasis in its new Defense Science and Technology Strategy, the DoD says that, although "technological superiority remains essential", it will also pursue two new goals, namely affordable weaponry and enhanced economic security.

But the department also says that it plans to "downsize, outsource and restructure" its science and technology infrastructure, including its own laboratories. Specific proposals will be submitted early in 1995 to the department-wide Base Realignment and Closure Commission.

"In the past we have focused on developing new capability, in some cases with not too much regard to cost," says Anita Jones, director of research and engineering at the DoD. "We can no longer do this on a reduced budget. We need to use technology to reduce the cost of systems. That is a new theme and a new objective for the science and technology program."

Introducing the strategy document last week, Jones added: "We want to make the defense technology investment nurture those technologies that are the base for both military products and commercial products.'

But John Deutch, deputy defence secretary and formerly dean of the Massachusetts Institute of Technology, sought to reassure

Their formal adoption in a strategy document at this stage is probably intended to help defend the science and technology programme from congressional budget-cutters - as well as some elements of the armed forces themselves - who regard it as extravagant and over-protected.

Last year, for example, a Senate appropriations committee described advanced technologies as representing "the un-affordable luxury of pursuing technology for technology's sake". But the DoD's research and development programme has been cut only marginally, while - as the strategy document notes -spending on weapons systems is being slashed by 60 per cent over a ten-year period.

Most of the \$36 billion to be spent by DoD this year on what

the armed forces that the new strategy will not reduce the quality of the DoD's research programme. "The strategy has one overall goal, to maintain the technological superiority of the United States," he said. (The strategy document itself says that technological superiority "remains essential", even if it is no longer "sufficient".)

The ideas of cost-effectiveness and dualuse technology are hardly new to the DoD.

\section{Germany beats UK to XMM contract}

Munich. The European Space Agency (ESA)'s Industrial Policy Committee (IPC) has decided to appoint Germany's DASA-Dornier as prime contractor for its XMM mission, a high-resolution X-ray telescope originally due to be launched at the end of the decade, although this date may be put back because of disagreements over the contracting process (see Nature 368, 87 ; 1994).

The decision over one of the four key 'cornerstone' missions of ESA's science programme was made despite the fact that a bid from British Aerospace received a higher assessment overall than that from Dornier, performing slightly less well on technical criteria, but better on management criteria.

A bid from Italy's Alenia Spazio was considered less attractive than either the German or British bids. The Italian company had led an earlier consortium bid for the ECU280-million (US\$338 million) contract, but failed because ESA felt it was too expensive and lacked acceptable proposals for programme management (see Nature 368, 87; 1994).
Space industry officials say that, in choosing Dornier over British Aerospace, ESA appealed to a rule, established by space ministers at a meeting in Grenada in 1992, that the 'industrial return coefficient' - the ratio of the value of contracts received by a country to its annual contribution to ESA - for each member state should not fall below 0.96 at the end of 1996, and should aspire to the ideal value of 1.0, embodying the concept of juste retour.

The IPC says that its decision will help to rectify the current imbalance of the industrial return coefficients. The United Kingdom had a coefficient of 1.04, representing a surplus of around ECU60 million a year. Germany's is 0.98 , representing a deficit of around ECU100 million.

But ESA's decision could also lead Britain to raise further questions about the functioning and activities of the space agency itself, particularly as it is concerned that overhead and management costs are biting into the agency's budget for space science (see page 546).

Alison Abbott it calls 'research, development, evaluation and test' (RDT\&E), will go on the development and trials of military systems. An estimated $\$ 4$ billion is spent on basic research and exploratory development. The universities spend $\$ 1.8$ billion of that - a figure that will fall by 10 per cent in the coming year - with the rest spread across industry and the DoD's own laboratories.

The new strategy offers five principles to guide the armed forces and defence agencies in managing science and technology: getting technology to the 'warfighters' more quickly; cutting costs; strengthening US industry; promoting basic research; and assuring quality.

The document also encourages $\mathrm{DoD}$ scientists to "monitor and collaborate in international science efforts". Jan Walker, a department spokeswoman, said that such collaboration would not be organized centrally, but was "in the hands of individual engineers and scientists".

A basic research programme is needed to ensure that the DoD "has early cognizance of new scientific ideas", the document says, pledging to "ensure stable funding for the highest priority efforts". Nevertheless, the document also commits the department to reducing its support for its own science and technology activities.

"The DoD must reassess the conditions under which it maintains in-house capability," the document says. "Today it may be more effective to rely on industry or universities for those technologies that are developing outside DoD at a rapid pace." But, as recent congressional reductions in DoD grants for university research demonstrate, such a shift in strategy may prove difficult to implement.

Colin Macilwain 